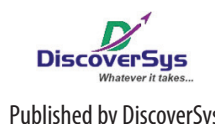

Published by DiscoverSys

\title{
Hospital facilities, occupational safety environment and self-efficacy as predictors of healthcare-associated infections prevention and control compliance in nurses of inpatient care units
}

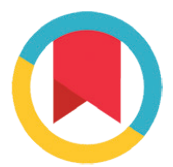

CrossMark

\author{
Luh Yulia Adiningsih, ${ }^{1 *}$ Ni Made Sri Nopiyani, ${ }^{2}$ I Made Ady Wirawan ${ }^{2}$
}

\section{ABSTRACT}

Background and purpose: The implementation of healthcareassociated infections (HAls) prevention and control program in hospitals remains sub-optimal. The present study aims to determine the relationships between nurse's self-efficacy, hospital's occupational safety environment, and the availability of facilities, with the compliance on HAls prevention and control in hospital inpatient care units.

Methods: Cross-sectional survey was conducted with 128 nurses selected using systematic random sampling at Buleleng District Hospital's inpatient care units. Data collection was conducted in March 2018 using self-administered questionnaires. The questionnaire consisted of five sections including characteristics of respondents, HAls prevention and control practices, self-efficacy, occupational safety environment and the availability of facilities. Bivariate analysis was conducted to calculate the Pearson correlation coefficients between variables. Multivariate analysis was performed with multiple linear regressions to examine self-efficacy, occupational safety environment and availability of facilities as predictors of the compliance on HAls prevention and control.
Results: The study shows that $56.2 \%$ of nurses reported good compliance on HAls prevention and control practices. Bivariate analysis shows a significant correlation between HAls prevention and control compliance scores and self-efficacy $(r=0.45 ; p=0.00)$, occupational safety environment $(r=0.53 ; p=0.00)$, and the availability of facilities $(r=0.65 ; p=0.00)$. Multivariate analysis shows that the availability of facilities is a significant predictor of HAls prevention and control compliance ( $\beta=0.49 ; p<0.01$ ) while self-efficacy and the occupational safety environment are also found to be significant predictors, although with lower standardized coefficients: $\beta=0.16(p=0.03)$ and $\beta=0.17(p=0.04)$, respectively.

Conclusion: The significant predictors of compliance on HAls prevention and control are availability of facilities, self efficacy and hospital's occupational safety environment. This study highlights the importance of optimizing the availability of facilities, improving the occupational safety environment, and enhancing nurses' self-efficacy in order to reduce the incidence of HAls in hospitals.

Keywords: Healthcare-associated infections, hospitals, facilities, occupational safety environment, self-efficacy

Cite This Article: Adiningsih, L.Y., Nopiyani, N.M.S., Wirawan, I.M.A. 2018. Hospital facilities, occupational safety environment and self-efficacy as predictors of healthcare-associated infections prevention and control compliance in nurses of inpatient care units. Public Health and Preventive Medicine Archive 6(2): 93-100. D01:10.15562/phpma.v6i2.96

TPublic Health Postgraduate Program Faculty of Medicine Udayana University, ${ }^{2}$ Department of Public Health and Preventive Medicine Faculty of Medicine Udayana University
*Correspondence to: Luh Yulia Adiningsih, Public Health Postgraduate Program Faculty of Medicine Udayana University lyauno@yahoo.com

\section{INTRODUCTION}

Healthcare-associated infections (HAIs) defined as the incidence of infection(s) among patients that may occur during their hospital care. ${ }^{1}$ HAIs in hospitals can be transmitted via blood (i.e. syringes etc.), ventilators, urinary-tract catheters and surgical wounds. ${ }^{1-3}$ Prevention of HAIs in developed countries such as the United States is committed as a top priority, ${ }^{4,5}$ however, HAIs remain widely reported in the developed countries. A study in the United States conducted at 183 hospitals showed that from a total of 11,282 patients, 452 (4.0\%) had contracted one or more HAI-related infections. ${ }^{6}$ In Australia, the incidence of HAIs was reported 83,096 cases per year which is considered very large underestimate due to the lack of or incomplete data on common infections.?

HAIs is a major challenge for low and middle income countries. ${ }^{8}$ In Asian countries, HAIs surveillance is rarely performed. ${ }^{9}$ Several studies in Indonesia showed that the prevention and control of HAIs remain inadequate. ${ }^{10-14}$ A routine report on the incidence of HAIs at a hospital in Surabaya, Indonesia, from 2012-2014 showed that HAIs rates ranged from $0.33 \%-0.59 \% .^{15}$ The incidences of HAIs related to surgical-wound infection at Buleleng District Hospital from May-July 2016 were $0.5 \%-0.7 \% .{ }^{16}$ The proportion of HAIs in Indonesia appears to be low may be due to the sub-optimal surveillance system and/ or the determination of HAIs diagnosis among patients in Indonesia. Some Indonesian hospitals did not report the incidence of HAIs. ${ }^{17,18}$ HAIs is a sensitive issue because they can negatively affect a hospital's reputation. The prevention and control of HAIs in Indonesia is regulated by the Ministry of Health Regulation No. 27 (2017) which involves 11 
aspects: hand hygiene, PPE use, decontamination of patient-care equipment, environmental health, waste management, linen management, health protection for hospital's workers, patients placement according to hospital procedures, cough and sneeze procedures, safe injection procedures, and lumbal punction. ${ }^{19}$ Studies related to predictors of HAIs incidence have been conducted both in Indonesia and other countries, however, most studies focused only on particular aspects, such as hand hygiene and PPE use only, without including all the other aspects. ${ }^{20-24}$ Studies on occupational safety environment and self-efficacy with HAIs are still limited. ${ }^{24-28}$ Some studies reported that the incidence of HAIs is related to the availability of facilities, but the results are inconsistent. ${ }^{26,29-32}$

This study aims to determine the association between self-efficacy, occupational safety environment and the availability of facilities, with the compliance on HAIs prevention and control at Buleleng District Hospital's inpatient care units.

\section{METHODS}

A cross-sectional survey was carried out in March 2018 in all inpatient care units of Buleleng District Hospital. This is a Type B Hospital and the only public and largest among five hospitals available in Buleleng District. ${ }^{33}$ The hospital has 333 bed ${ }^{34}$ with the average bed occupancy rate of $76.12 \% .^{35}$ There are a total number of 199 nurses in charged for inpatient care units and 128 nurses were selected as sample for this study using systematic random sampling. The sample size was calculated based on the following parameters: mean score of hand hygiene behaviour of 3.96, standard deviation of $2.1{ }^{36}$ anticipated mean score of $4.5,95 \%$ confidence level and power of $80 \%$. The data were collected using self-administered questionnaires that had been pre-tested among 20 nurses at a different hospital. The questionnaire consisted of five sections: (i) characteristics of respondents (ii) HAIs prevention and control practices, (iii) self-efficacy, (iv) occupational safety environment and (v) the availability of facilities. The questionnaire of HAIs prevention and control practices was developed referring to the Ministry of Health Regulation No. 27 (2017) which comprised of 50 items examining ten aspects. ${ }^{19}$ They are hand hygiene, PPE use, decontamination of patient-care equipment, environmental health, waste management, linen management, health protection for hospital's workers, patients placement according to hospital procedures, cough and sneeze procedures and safe injection procedures. The self-efficacy questionnaire was adopted from Bijl \& Baggett's ${ }^{37}$ which consists of 12 statements related to the aspects of magnitude, strength, and generality. The questionnaire of occupational safety environment was adopted from Schneider's ${ }^{38}$ consisting of 15 statements covering three aspects of policies, practices and procedures. The questionnaire on the availability of facilities refers to the ministerial regulations regarding the technical requirements for hospital buildings and facilities ${ }^{39}$ which consists of 26 items covering equipment and supporting facilities. Some items consist of four options: "strongly agree", "agree", "disagree" and "strongly disagree". Other items consist of: "always", "often", "sometimes" and "never". The options of "agree" or "always" were assigned a score of four; "agree" or "often" a score of three; "disagree" or "sometimes" a score of two, and "strongly disagree" or "never" a score of one.

The scores from each item were then summed to obtain a total score for each section namely: the total score of compliance on HAIs prevention and control; self-efficacy; occupational safety environment and facility availability. To understand the proportion of the nurses who comply with the HAIs prevention and control, the total scores from each section were grouped into two categories: "high" and "low"; "good" and "poor"; or "complete" and "incomplete", with the mean as the cut-off point for each section.

Bivariate analysis was conducted to calculate the Pearson's correlation coefficient between variables and Kolmogorov-Smirnov test was used to determine how likely the data are normally distributed. Multivariate analysis was performed with multiple linear regressions to examine self-efficacy, occupational safety environment and availability of facilities as predictors of the compliance on HAIs prevention and control. This study has been approved by the Ethics Committee of the Faculty of Medicine, Udayana University/ Sanglah General Hospital on February 21, 2018.

\section{RESULTS}

Table 1 presents the characteristics of respondents with majority of females, married, aged $<25$ years, diploma of nursing, contract workers and have worked in the hospital for less than 6 years.

Table 2 presents the proportions of respondents who scored well on HAIs prevention and control items. Overall, $56.2 \%$ of nurses reported implementing "good" HAIs prevention and control. In terms of the specific HAIs prevention and control practices: $68.8 \%$ reported "good" hand hygiene practices; $60.9 \%$ "good" PPE use; $60.9 \%$ decontaminating patient-care equipment; $53.1 \%$ have followed environmental health procedures; $64.8 \%$ have followed good waste management 
Table 1 Characteristics of respondents

\begin{tabular}{|c|c|c|}
\hline Variables & $\mathbf{n}$ & $\%$ \\
\hline \multicolumn{3}{|l|}{ Sex } \\
\hline Male & 18 & 14.1 \\
\hline Female & 110 & 85.9 \\
\hline \multicolumn{3}{|l|}{ Marital status } \\
\hline Unmarried & 31 & 24.2 \\
\hline Married & 96 & 75.0 \\
\hline Widows/widowers & 1 & 0.8 \\
\hline \multicolumn{3}{|l|}{ Age } \\
\hline$<25$ years & 17 & 13.3 \\
\hline 25-34years & 85 & 66.4 \\
\hline$>35$ years & 26 & 20.3 \\
\hline \multicolumn{3}{|l|}{ Education } \\
\hline High school graduate & 2 & 1.6 \\
\hline Diploma of Nursing & 64 & 50 \\
\hline Bachelor of Nursing & 14 & 10.9 \\
\hline Ners (bachelor plus one year professional education) & 48 & 37.5 \\
\hline \multicolumn{3}{|l|}{ Employment } \\
\hline Government employee & 43 & 33.6 \\
\hline Contract worker & 85 & 66.4 \\
\hline \multicolumn{3}{|l|}{ Working period } \\
\hline$\leq 5$ years & 67 & 52.3 \\
\hline$>5$ years & 61 & 47.7 \\
\hline Total & 128 & 100.0 \\
\hline
\end{tabular}

Table 2 Proportion of nurses based on the implementation of HAls prevention and control

\begin{tabular}{lll}
\hline Implementation of HAls prevention and control & $\mathbf{n}$ & $\%$ \\
\hline Hand hygiene & & 31.2 \\
Poor & 40 & 68.8 \\
Good & 88 & 39.1 \\
PPE use & 50 & 60.9 \\
Poor & 78 & 39.1 \\
Good & & 60.9 \\
Decontamination of patient-care equipment & 50 & 46.9 \\
Poor & 78 & 53.1 \\
Good & & \\
Environment health & 60 & 35.2 \\
Poor & 68 & 64.8 \\
Good & & \\
Waste management & 45 & 59.2 \\
Poor & 83 & \\
Good & 63 & \\
Linen management & & \\
Poor & & \\
Good & &
\end{tabular}


Table 2 Continue

\begin{tabular}{|c|c|c|c|c|}
\hline \multicolumn{3}{|c|}{ Implementation of HAls prevention and control } & $\mathbf{n}$ & $\%$ \\
\hline \multicolumn{5}{|c|}{ Health protection for hospital's workers } \\
\hline \multicolumn{2}{|l|}{ Poor } & & 59 & 46.1 \\
\hline \multicolumn{2}{|l|}{ Good } & & 69 & 53.9 \\
\hline \multicolumn{5}{|c|}{ Patient placement } \\
\hline \multicolumn{2}{|c|}{ Poor } & & 70 & 54.7 \\
\hline \multicolumn{2}{|l|}{ Good } & & 58 & 45.3 \\
\hline \multicolumn{5}{|c|}{ Cough and sneeze procedures } \\
\hline \multicolumn{2}{|l|}{ Poor } & & 58 & 45.3 \\
\hline \multicolumn{2}{|l|}{ Good } & & 70 & 54.7 \\
\hline \multicolumn{5}{|c|}{ Safe injection procedures } \\
\hline \multicolumn{2}{|c|}{ Poor } & & 28 & 21.9 \\
\hline \multicolumn{2}{|c|}{ Good } & & 100 & 78.1 \\
\hline \multicolumn{5}{|c|}{ Overall implementation of HAIs prevention and control } \\
\hline \multicolumn{2}{|c|}{ Poor } & & 56 & 43.8 \\
\hline \multicolumn{2}{|l|}{ Good } & & 72 & 56.2 \\
\hline \multicolumn{2}{|l|}{ Total } & & 128 & 100.0 \\
\hline \multicolumn{5}{|c|}{$\begin{array}{l}\text { Table } 3 \text { Proportions and descriptive statistics for self-efficacy, occupational safety } \\
\text { environment, availability of facilities, and the implementation of HAls prevention } \\
\text { and control }\end{array}$} \\
\hline \multicolumn{2}{|l|}{ Variables } & No of item & n (\%) & Mean (SD) \\
\hline \multicolumn{2}{|c|}{ Self-efficacy } & 12 & & $41.8(3.9)$ \\
\hline \multicolumn{2}{|l|}{ High } & & $67(52.3)$ & \\
\hline \multicolumn{2}{|l|}{ Low } & & $61(47.7)$ & \\
\hline \multicolumn{2}{|c|}{ Occupational safety environment } & 15 & & $48.6(5.7)$ \\
\hline \multicolumn{2}{|c|}{ Good } & & $68(53.1)$ & \\
\hline \multicolumn{2}{|c|}{ Poor } & & $60(46.9)$ & \\
\hline \multicolumn{2}{|c|}{ Availability of facilities } & 26 & & $79.8(11.1)$ \\
\hline \multicolumn{2}{|c|}{ Complete } & & $67(52.3)$ & \\
\hline \multicolumn{2}{|c|}{ Incomplete } & & $61(47.7)$ & \\
\hline \multicolumn{2}{|c|}{ Overall implementation of HAIs prevention and control } & 50 & & $171.5(17.8)$ \\
\hline \multicolumn{2}{|l|}{ Good } & & $72(56.2)$ & \\
\hline \multicolumn{2}{|l|}{ Poor } & & $56(43.8)$ & \\
\hline
\end{tabular}

practices; $50.8 \%$ have adhered to good linen management practices; $53.9 \%$ had "good" health protection for hospital's workers; $45.3 \%$ adhering to good patient placement according to hospital procedures; $54.7 \%$ have followed good cough and sneeze protocols; and $78.1 \%$ have followed safe injection procedures.

Table 3 presents the proportions of respondents based on the following variables: self-efficacy, occupational safety environment, availability of facilities and implementation of HAIs prevention and control. The proportion of respondents with "high" self-efficacy was $52.3 \%$. Within each section, the proportion of nurses with "good" self-confidence in completing tasks (magnitude) was $56.2 \%$; "good" strength in completing nursing tasks was 55.5\%, while "good" self-confidence in facing a variety of situations (generality) was only $39.1 \%$. The proportion of respondents who reported the occupational safety environment as "good" was 53.1\%. Within each section, nurses who rated "good" for hospital policy were $69.5 \%$, for procedural aspects $56.2 \%$, and for hospital practices $47.7 \%$. The overall proportion of respondents who reported "adequate" availability of facilities was $52.3 \%$. For each section, respectively $51.6 \%$ 
Table 4 Pearson's correlation coefficient ( $R$ ) between self-efficacy, occupational safety environment and availability of facilities, with the implementation of HAls prevention and control

\begin{tabular}{|c|c|c|c|c|}
\hline Variable & $\begin{array}{c}\text { Self-efficacy } \\
(\mathbf{r})\end{array}$ & $\begin{array}{c}\text { Occupational-safety } \\
\text { environment } \\
(\mathbf{r})\end{array}$ & $\begin{array}{c}\text { Availability of } \\
\text { facilities } \\
\text { (r) }\end{array}$ & $\begin{array}{c}\text { Application of HAls } \\
\text { prevention and control } \\
\text { (r) }\end{array}$ \\
\hline Self-efficacy & 1 & 0.51 & 0.41 & 0.45 \\
\hline $\begin{array}{l}\text { Occupational safety } \\
\text { environment }\end{array}$ & 0.51 & 1 & 0.56 & 0.53 \\
\hline Availability of facilities & 0.41 & 0.56 & 1 & 0.65 \\
\hline $\begin{array}{l}\text { Implementation of HAIs } \\
\text { prevention and control }\end{array}$ & 0.45 & 0.53 & 0.65 & 1 \\
\hline
\end{tabular}

Table 5 Standardized coefficients between self-efficacy, occupational safety environment and availability of facilities with the implementation of HAls prevention and control

\begin{tabular}{|c|c|c|c|c|c|}
\hline & \multicolumn{2}{|c|}{$\begin{array}{l}\text { Unstandardized } \\
\text { Coefficients }\end{array}$} & \multirow{2}{*}{$\begin{array}{c}\begin{array}{c}\text { Standardized } \\
\text { Coefficients }\end{array} \\
\text { Beta }\end{array}$} & \multirow[b]{2}{*}{$\mathbf{t}$} & \multirow[b]{2}{*}{$\mathbf{p}$} \\
\hline & B & Standard Error & & & \\
\hline (Constant) & 52.03 & 12.92 & - & 4.03 & $<0.01$ \\
\hline Self-efficacy & 0.73 & 0.34 & 0.16 & 2.15 & 0.03 \\
\hline Occupational safety environment & 0.52 & 0.26 & 0.17 & 2.02 & 0.04 \\
\hline Availability of facilities & 0.79 & 0.12 & 0.49 & 6.25 & $<0.01$ \\
\hline
\end{tabular}

$\mathrm{R}=0.70$

$\mathrm{R}$ square $=0.49$

Adjusted R square $=0.48$

$\mathrm{F}=39.43$

Sig. $\mathrm{F}=0.00$

and $44.5 \%$ nurses agreed that the equipment and supporting facilities were "adequate".

Table 4 shows the Pearson's ( $r$ ) correlation coefficient matrix to determine the association(s) between the variables. The coefficient correlation between the implementation of HAIs prevention and control with self-efficacy was 0.45 ; with the occupational safety environment 0.53 ; and with the availability of facilities 0.65 . We also found a relationship between the independent variables: namely, self-efficacy and occupational safety environment $(\mathrm{r}=0.51)$, self-efficacy and the availability of facilities $(r=0.41)$, and the occupational safety environment and the availability of facilities $(\mathrm{r}=0.56)$.

Table 5 illustrates the results of multivariate analysis using multiple linear regressions to determine the association between self-efficacy, occupational safety environment and facilities availability with the compliance on HAIs prevention and control. The normality test conducted using One Sample Kolmogorov-Smirnov showed insignificant results for self-efficacy ( $\mathrm{p}=0.06)$; occupational safety environment $(\mathrm{p}=0.46)$; facilities availability $(\mathrm{p}=0.86)$ and the implementation of HAIs prevention and control $(p=0.08)$. Multiple regression analysis showed that the standardized coefficients (Beta) for self-efficacy was $0.16(\mathrm{p}=0.03)$; occupational safety environment $=0.17 \quad(\mathrm{p}=0.04)$; and facilities availability $=0.49 \quad(\mathrm{p}<0.01)$, with the equation of $\mathrm{Y}=0.16 \mathrm{X} 1+0.17 \mathrm{X} 2+0.49 \mathrm{X} 3$. The $\mathrm{R}$ square value was $0.49(\mathrm{~F}=39.43, \mathrm{p}=0.00)$.

\section{DISCUSSION}

This study investigated the implementation of HAIs prevention and control in 10 aspects (hand hygiene, PPE use, decontamination of patient care equipment, environmental health, waste management, linen management, health protection of hospital's workers, placement of patients, coughing and sneezing procedures, and safe injection procedures).

The results indicated that $56.2 \%$ of nurses at Buleleng District Hospital's inpatient care units reported "good" compliance on HAIs prevention and control. In terms of each aspect in the HAIs prevention and control, respondents had the highest score in safe injection procedures (78.1\%) while the lowest score in patient placement (45.3\%). In our study, patient placement refers to the practice of separating patients with infectious diseases from those with non-infectious diseases.

A study at Prof. Dr. R.D. Kandou General Hospital in Manado found that $88.3 \%$ of nurses correctly followed HAIs prevention and 
control procedures. ${ }^{21}$ Other studies reported the implementation of HAIs prevention and control in hospitals only in a specific aspect. A study at Banjarmasin Islamic Hospital's inpatient care units showed that $98.5 \%$ of nurses followed hand hygiene procedures while at RS "X" in Malang only 35\%. ${ }^{22,23}$ In our study, $68.8 \%$ of nurses reported "good" hand hygiene practices. Other study in developed countries, carried out at a Belgium hospital's ICU ward, showed that $82 \%$ of nurses adhered to handhygiene practices in the prevention of HAIs. ${ }^{20}$ This finding shows that adherence to good hand hygiene practices was higher than that found at the hospital in Malang and the Buleleng District Hospital, but lower than the Banjarmasin Islamic Hospital. These differences are likely due to the different settings of the studies, namely an ICU ward and inpatient care units. Additionally, the differences may be due to how hand hygiene was measured and the standards used in each study.

The other aspects of HAIs prevention and control which widely publicized were PPE use and safe injection procedures. The present study at Buleleng District Hospital found that $60.9 \%$ of nurses "correctly" used PPE, whereas $81.7 \%$ reported in the study at Kandou General Hospital in Manado and $86.2 \%$ at Banjarmasin Islamic Hospital. $^{21,22}$ Nurses' adherence to safe injection procedures at Buleleng District Hospital was 78.1\% while in the Manado study was reported $81.7 \%$, and $83.1 \%$ at Banjarmasin Islamic Hospital. ${ }^{21,22}$ These findings indicate that the compliance on PPE use and safe injection procedures at Buleleng District Hospital's inpatient care units is lower compared to those at Kandou General Hospital in Manado and Banjarmasin Islamic Hospital.

A number of qualitative studies have reported that the obstacles to implementing HAIs prevention and control for nurses include limited human resources; limited hospital resources; lack of training, weak monitoring and evaluation, inadequate facilities, lack of awareness among hospital staff, inconsistent recording of cases of HAIs and sub-optimal staff commitment to preventing and controlling HAIs. ${ }^{40-42}$

In our study, significant predictors of HAIs prevention and control compliance were the availability of facilities, self-efficacy and occupational safety environment. Other studies show that self-efficacy is also a predictor of HAIs prevention and control compliance although only in a specific aspect. For instance, the Belgian ICU study showed that self-efficacy was significantly associated with hand hygiene $(\beta=0.37 ; \mathrm{p}=0.00){ }^{20}$ Another study at the Ministry of Interior Security
Hospital, Saudi Arabia, reported that self-efficacy is positively related to hand hygiene for the prevention and control of HAIs. ${ }^{24}$ Similar studies at 18 hospitals in Hunan Province, China, reported that adherence to HAIs prevention and control practices is influenced by self-efficacy. ${ }^{25}$ However, our findings differ from the above studies in terms of respondents' characteristics, place, data-collection methods and the types of HAIs prevention and control practices investigated.

Several other studies also show similar results in terms of predictors of hospital's occupational safety environment. For example, studies at Bhayangkara Hospital in Manado, the Red Cross Hospital in Bogor and Banyumas Hospital show that hospital's occupational safety environment correlates significantly with HAIs prevention and control..$^{26-28}$

Several other studies also show that the availability of facilities is related to the implementation of HAIs prevention and control (e.g. studies at the inpatient ward at a district hospital in Jakarta, also Bhayangkara Hospital and Kandou General Hospital in Manado). ${ }^{26,30}$ However, other studies at Dr. Sardjito Hospital and " $\mathrm{X}$ " Hospital in Jakarta suggest that there is no significant relationship between hospital facilities and HAIs prevention and control. ${ }^{31,32}$

In this type of studies, direct observation is considered as the gold standard to measure the HAIs prevention and control practices. In our study, the measurement relies on a self-reported questionnaire, which potentially becomes the source of biases. Respondents might feel uncomfortable in providing an answer that suggested inappropriate practices or conditions. Another limitation is that the questionnaire was not tested for its validity and reliability. This study was conducted at only one hospital with a sample of nurses working in the inpatient ward, thus precautions should be taken in generalising the results to the broader patient-care contexts.

\section{CONCLUSION}

The lowest compliance on HAIs prevention and control was the patient placement. Availability of facilities, occupational safety environment and self-efficacy were significantly found as predictors of compliance on HAIs prevention and control. This study underlines that in order to reduce the incidence of HAIs in hospitals, there is a need to improve hospital facilities, the occupational safety environment, as well as nurses' self-efficacy, for example by implementing more intensive HAIs prevention and control training and supervision. 


\section{ACKNOWLEDGEMENT}

We would like to thank the Director of Buleleng District Hospital, all nurses at inpatient care units, and others who have assisted the implementation of this study.

\section{REFERENCES}

1. World Health Organization. Prevention of hospital-acquired infections: A Practical Guide $2^{\text {nd }}$ Edition. 2002; 1-64.

2. Lardo S, Prasetyo B, Purwaamidjaja DB. Infection control risk assessment (ICRA). Cermin Dunia Kedokteran. 2016; 43(3): 215-9.

3. Centers for Disease Control and Prevention. Types of healthcare-associated infections. 2014. (serial online), [cited 2018 Sept. 02]. Available from: https://www.cdc.gov/ HAIs/infection types.html.

4. Office of Disease Prevention and Health Promotion. Healthcare-associated infections. 2014. (serial online), [cited 2018 Sept. 02]. Available from: https://www. healthypeople.gov/2020/topics-objectives/topic/ healthcareassociatedinfection.

5. Centers for Disease Control and Prevention. Preventing healthcare-associated infections. 2015. (serial online), [cited 2018 Sept. 01]. Available from: https://www. cdc. gov/HAIs/ prevent/prevention.html.

6. Magill SS, Edwards JR, Bamberg W, Beldavs ZG, Dumyati G, Kainer MA, et al. Multistate point-prevalence survey of health care-associated infections. New England Journal of Medicine. 2014; 370(13): 1198-1208.

7. Mitchell BG, Shaban RZ, MacBeth D, Wood CJ, Russo PL. The burden of healthcare-associated infection in Australian hospitals: a systematic review of the literature. Infection, Disease, and Health. 2017; 22(3): 117-28.

8. Shahida SM, Islam A, Dey BR, Islam F, Venkatesh K, Goodman A. Hospital acquired infections in low and middle income countries: root cause analysis and the development of infection control practices in Bangladesh. Open Journal of Obstetrics and Gynecology. 2016; 6(1): 28-39.

9. Ling ML, Apisarnthanarak A, Madriaga G. The burden of healthcare-associated infections in Southeast Asia: A systematic literature review and meta-analysis. Clinical Infectious Diseases. 2015; 60(11): 1690-1699.

10. Satiti A. Analisis penerapan standard precaution dalam pencegahan dan pengendalian HAIs di RSUD RAA Soewondo Pati [Analysis of standard precaution implementation in the prevention and control of HAIs at RAA Sowondo Pati Hospital]. Jurnal Kesehatan Masyarakat. 2017; 5 (1): 40-49.

11. Sapardi VS. Analisis pelaksanaan manajemen pencegahan dan pengendalian healthcare associated infections di RSI Ibnu Sina [Analysis on the implementation of HAIs prevention and control management at Ibnu Sina Hospital]. Jurnal Endurance. 2018; 3(2): 358-366.

12. Nurani RRS. Gambaran kepatuhan hand hygiene pada perawat hemodialisis di RSU Haji Surabaya [Compliance on hand hygiene practice among hemodialysis nurses at Surabaya Haji Hospital]. Surabaya: Universitas Airlangga; 2017; 218-230.

13. Kartika Y. Faktor sumber daya manusia dan komitmen manajemen yang mempengaruhi surveillance infeksi nosokomial di Rumah Sakit Paru Batu [Human resources and management commitment which influence surveillance of nosocomial infections at Batu Lung Hospital]. Malang: Universitas Brawijaya; 2015; 28(2): 181-185.

14. Paparang FS. Analisis penerapan pencegahan dan pengendalian infeksi di Poli Gigi RSUD Tobelo Kabupaten Halmahera Utara [Analysis of infections prevention and control at Dental Polyclinic, Tobelo Hospital, North Halmahera Regency]. Manado: Universitas Sam Ratulangi. 2018; 1-17.
15. Putri APS. Bundle prevention form filling completeness of surgical site infection (SSI) on sectio caesarean patients. Jurnal Berkala Epidemiologi. 2017; 5(1):13.

16. Buleleng District Hospital. Data kejadian HAIs di RSUD Kabupaten Buleleng Tahun 2016 [Data on the prevalence of HAIs at Buleleng District Hospital 2016]. 2016.

17. Sari D. Infection control risk assessment (ICRA) di Instalasi Bedah Central RS PKU Muhammadiyah Gamping (tesis) [Infection control risk assessment (ICRA) at the Central Surgery Unit PKU Muhammadiyah Gamping Hospital (thesis)]. Yogyakarta: Universitas Muhammadiyah; 2016; $1-15$.

18. Rahwan A. Manajemen perawatan pasien total care dan kejadian infeksi nosokomial di ruang ICU RSUD Masohi tahun 2016 [Management of total care patients and the incidence of nosocomial infections at the ICU Masohi Hospital 2016]. 2017; 2(3): 319-324

19. Ministry of Health of Indonesia. Peraturan Menteri Kesehatan Nomor 27 Tahun 2017 tentang Pedoman Pencegahan dan Pengendalian Infeksi di Fasilitas Pelayanan Kesehatan [Health Ministry Act No. 27, 2017 on the Guidelines of Infections Prevention and Control at Health Services]. 2017; 1-172.

20. De Wandel D, Maes L, Labeau S, Vereecken C, Blot S. Behavioral determinants of hand hygiene compliance in intensive care units. American Journal of Critical Care. 2010; 19(3): 230-9.

21. Rotti G. Pelaksanaan pencegahan dan pengendalian infeksi di ruang rawat inap Rumah Sakit Umum Pusat Prof. R.D Kandou Manado [The implementation of infections prevention and control at inpatient ward, Prof. R.D Kandou Hospital in Manado]. JST Kesehatan; 2014; 4(1): 69-77.

22. Amaliah N. Pengembangan kinerja perawat terhadap pencegahan infeksi flebitis di rumah sakit [Development of nurses work performance towards the flebitis infection prevention in a hospital]. Caring Nursing Journal. 2017; 1(2): 69-78.

23. Ernawati E. Penerapan hand hygiene perawat di ruang rawat inap rumah sakit [Hand hygiene practice of nurses at a hospital inpatient ward]. Jurnal Kedokteran Brawijaya. 2014; 28(1): 89-94.

24. Tan A, Olivo J. Assessing healthcare associated infections and hand hygiene perceptions amongst healthcare professionals clinical nurse specialist. International Journal of Caring Sciences. 2015; 8(1): 108-115.

25. Luo Y, He GP, Zhou JW, Luo Y. Factors impacting compliance with standard precautions in nursing, China. International Journal of Infectious Diseases. 2010; 14(12): e1106-14.

26. Lantu J. Analisis penerapan standard precautions oleh perawat di Rumah Sakit Bhayangkara TK III Manado [Analysis on the standard precautions implementation in nurses at Manado Bhayangkara Hospital]. Manado: Universitas Sam Ratulangi; 2015; 98-106.

27. Sahara A. Faktor-faktor yang berhubungan dengan kepatuhan perawat dan bidan dalam penerapan kewaspadaan universal/kewaspadaan standar di Rumah Sakit Palang Merah Indonesia Bogor [Factors associated with compliance of nurses and midwives in the universal/ standard precautions implementation at the Bogor Indonesia Red Cross Hospital]. Jakarta: Universitas Indonesia; 2011:1-156.

28. Purnomo R. Analisis faktor-faktor yang berhubungan dengan ketergantungan perawat terhadap penerapan kewaspadaan standar di Rumah Sakit Umum Banyumas [Analysis of factors associated with nurses compliance on standard precaution implementation at the Banyumas General Hospital]. Jurnal Keperawatan dan Kesehatan. 2016; (1): 41-45.

29. Rotinsulu R. Hubungan antara pengetahuan, ketersediaan sarana, dan motivasi dengan kepatuhan penerapan kewaspadaan standar oleh dokter gigi di Poliklinik Gigi dan Mulut Rumah Sakit Kota Manado [Association between knowledge, facilities and motivation with compliance on standard precautions implementation among dentists at Dental Polyclinic Manado Hospital]. Manado: Universitas Sam Ratulangi; 2017; 64-80. 
30. Runtu L. Faktor-faktor yang berhubungan dengan perilaku perawat dalam penerapan universal precautions [Factors associated with implementation of universal precautions among nurses]. Juiperdo. 2013; 2(1).

31. Bady A. Analisis kinerja perawat dalam pengendalian infeksi nosokomial di IRNA I RSUP dr.Sardjito [Work analysis of nurses in nosocomial infection control at an inpatient ward dr. Sardjito Hospital]. Working Paper Series. 2007; (8).

32. Atmadja L. Analisis perilaku perawat dalam pencegahan infeksi nosokomial di ruang rawat inap RSUD X Jakarta (tesis) [Analysis on the nosocomial infection prevention among nurses at inpatient ward of Hospital X Jakarta (thesis)]. Depok: Universitas Indonesia; 2012:1-203.

33. Buleleng District Hospital. Dialog interaktif dengan tokoh masyarakat \& stakeholder terkait peningkatan mutu pelayanan di RSUD Kabupaten Buleleng (Interactive dialogue with community stakeholders on increasing the service quality at Buleleng District Hospitall. 2018.

34. Buleleng District Hospital. Data statistik RSUD Kabupaten Buleleng [Statistics of Buleleng District Hospital]. 2018.

35. Buleleng Statistics Office. Buku statistik infrastruktur daerah [Statistics book of local infrastructures]. 2017: 1-174.

36. Fauzi N, Ahsan, Azzuhri M. Pengaruh faktor individu, organisasi dan perilaku terhadap kepatuhan perawat dalam melaksanakan hand hygiene di ruang rawat inap Rumah Sakit Tk. II dr. Soepraoen Malang [The influence of individual, organisation and behavior factors to the compliance of nurses on hang hygiene practice at an inpatient ward dr. Soepraoen Hospital, Malang]. Jurnal Aplikasi Manajemen. 2015; 13(4): 566-74.

37. Van der Bijl JJ, Shortridge-Baggett LM. The theory and measurement of the self-efficacy construct. Scholarly Inquiry for Nursing Practice. 2001; 15(13): 189-207.
38. Schneider B, Ehrhart MG, Macey WH. Organizational climate and culture. Annual Review of Psychology; 2013;64(1):361-388

39. Ministry of Health of Indonesia. Persyaratan teknis bangunan dan prasarana rumah sakit [Technical requirements on hospitals' building and facilities]. 2016; $1-211$.

40. Octavia C. Analisis kemampuan perawat dalam pencegahan dan pengendalian infeksi nosokomial di Rumah Sakit Umum Mitra Medika Medan (tesis) [Analysis of nurses' competencies in nosocomial infections prevention and control at Mitra Medika Hospital, Medan (thesis)]. Universitas Sumatera Utara; 2016: 1-127.

41. Al'amri M. Analisis implementasi pencegahan dan pengendalian infeksi di RSU Anutapura Palu (tesis) [Analysis on the infections prevention and control at Anutapura Hospital, Palu (thesis)]. Makassar: Universitas Hasanuddin; 2017: 1-141.

42. Adhiwijaya A. Pelaksanaan pencegahan dan pengendalian infeksi dalam peningkatan mutu pelayanan di RSUD Labuang Baji (tesis) [Implementation of infections prevention and control in increasing the service quality at Labuang Baji Hospital (thesis)]. Makassar: Universitas Hasanuddin; 2017: 1-160.

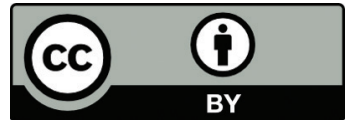

This work is licensed under a Creative Commons Attribution 